\title{
Prevention of Vasospasm after Subarachnoid Hemorrhage in Dogs by Continuous Intravenous Infusion of PD156707
}

\author{
R. Loch MACDOnALD, Lydia JOHnS, George Lin, Linda S. MARTON, \\ Hussein HALLAK*, Frank MARCOUX*, and Andrew KOWALCZUK
}

Section of Neurosurgery, Department of Surgery, University of Chicago Medical Center, Chicago, Illinois, U.S.A.; *Parke Davis Pharmaceutical Research, Ann Arbor, Michigan, U.S.A.

\begin{abstract}
This randomized, blinded study tested the prophylactic effect of PD156707, a nonpeptide competitive antagonist of endothelin A receptors, against vasospasm after subarachnoid hemorrhage in dogs. Twenty-two dogs were allocated on day 0 to undergo cerebral angiography followed by injection of arterial blood $(0.5 \mathrm{ml} / \mathrm{kg})$ into the cisterna magna. Dogs had central venous catheters implanted for continuous infusion of drug vehicle $(n=10)$ or PD156707 $(n=12)$. Cisternal blood injection was repeated on day 2 . Drug levels were measured in plasma on days $2,4,6$, and 7 and in cerebrospinal fluid (CSF) on days 2 and 7 . Angiography was repeated on day 7 to assess vasospasm. After angiography on day 7 , acute effects of infusion of PD156707, $100 \mathrm{mg}$, or drug vehicle on established vasospasm were assessed. Analysis of physiological variables within (analysis of variance) groups across time and between (unpaired t-test) groups at each time showed that drug-treated animals had significantly increased heart rate on day 7 compared to day $0(p<0.005)$. Comparison of basilar artery diameters at day 7 showed that PD156707 significantly decreased the degree of basilar artery vasospasm (placebo: $-47 \pm 5 \%$ reduction [mean $\pm \mathrm{SE}$ ] versus PD156707: $-28 \pm 7 \%, p<0.05$, unpaired $t$-test). There was, however, significant vasospasm when comparing within groups (paired t-test, placebo: $p<0.0001$, PD156707: $p$ $<0.005)$. Mean plasma PD156707 levels $(322 \pm 123 \mathrm{ng} / \mathrm{ml})$ were adequate to block responses of endothelin-1 on endothelin A receptors in vitro although CSF levels $(11 \pm 7 \mathrm{ng} / \mathrm{ml})$ were substantially lower. Infusion of PD156707 into the basilar artery on day 7 caused a small but significant $10 \pm 3 \%$ (paired ttest, $p<0.01)$ increase in diameter compared to placebo $(3 \pm 3 \%$ increase, $p=0.32)$. This infusion also was associated with a substantial increase in CSF drug levels to $19 \pm 9 \mathrm{mg} / \mathrm{ml}$. These results suggest that endothelin A receptors mediate some of the vasospasm that occurs after SAH in dogs and that blockade of these receptors may be a beneficial treatment for vasospasm.
\end{abstract}

Key words: cerebral vasospasm, dog, endothelin, subarachnoid hemorrhage

\section{Introduction}

The endothelins (ET) are three related 21-amino acid peptides that are potent modulators of vascular tone, inducing vasoconstriction and under some conditions, vasodilation, as well as smooth muscle proliferation. They act on cell surface receptors that have been classified in mammals as $\mathrm{ET}_{\mathrm{A}}$ and $\mathrm{ET}_{\mathrm{B}}$. The role of ET-2 is less certain in the cerebral vasculature and most work of relevance to vasospasm and subarachnoid hemorrhage (SAH) has involved ET-1.

Increased synthesis of ET-1 by cerebrovascular endothelial and possibly other central nervous system cells has been postulated to contribute to smooth muscle contraction and vasospasm after $\mathrm{SAH}^{1,9,29)}$ It follows that antagonism of the action of ET-1 might diminish vasospasm. In support of this, a number of studies have demonstrated efficacy of ET receptor antagonists against vasospasm in various animal models. ${ }^{1-3,5,10-16,21,22,26,28,32,34-36)}$ A limitation of most of these antagonists was that they are peptides that would need to be administered intracisternally in order to prevent vasospasm. This study tested the effects of a potent $\mathrm{ET}_{\mathrm{A}}$ receptor antagonist that crosses the blood brain barrier and would be expected to be active against vasospasm when administered systemically. ${ }^{24)}$ The endpoints utilized were the degree of vasospasm assessed by comparison of arterial diameters on angiograms taken at baseline and 7 days after cisternal blood injection and drug administration, the levels of ET-1 plus ET-2 in cerebrospinal 
fluid (CSF) and the basilar artery, and intravenous and CSF plasma levels of the drug. The effect on arterial diameter of infusion of PD156707 or vehicle into the basilar artery on day 7 was also assessed.

\section{Materials and Methods}

\section{Protocol}

All procedures involving animals were carried out by investigators blinded to group allocation and were approved by the institutional animal care and use committee. On day 0 , mongrel dogs weighing between 10 and $20 \mathrm{~kg}$ were randomly allocated to undergo baseline cerebral angiography followed by injections of autologous blood into the cisterna magna on days 0 and 2 . They were randomized to receive drug vehicle or PD156707, $0.3 \mathrm{mg} / \mathrm{kg} / \mathrm{day}$, by continuous intravenous infusion starting on day 0 and continuing for 7 days. Angiography was repeated on day 7. After angiography on day 7, PD156707, 100 $\mathrm{mg}$, or an equivalent volume of drug vehicle was infused into the basilar artery and angiography was repeated. The animals were then euthanized. Levels of PD156707 were measured in plasma obtained from a peripheral vein on days $0,2,4,6$, and 7 and on CSF on days 0,2 , and 7 . The level of ET- 1 was measured in CSF on days 0,2 , and 7 and in the basilar artery on day 7.

\section{Angiography, creation of SAH}

On day 0 , dogs were weighed and anesthetized with sodium thiopental, 15 to $20 \mathrm{mg} / \mathrm{kg}$, intravenously. They were endotracheally intubated and positioned supine and ventilated on a mixture of $\mathrm{O}_{2}$ and $1 \%$ to $3 \%$ isoflurane. End-tidal $\mathrm{PCO}_{2}$, heart rate, and blood pressure were monitored continuously using a noninvasive monitor (Criticon Dinamap Research Monitor; Criticon, Tampa, Fla., U.S.A.). Body temperature was maintained with a water-heated blanket (Gaymar model TP-200; Gaymar, Orchard Park, N.Y., U.S.A.). The left femoral artery was cannulated using sterile technique and a 5-French catheter was advanced into the proximal left vertebral artery. Arterial blood gases were obtained and the $\mathrm{PaCO}_{2}$ was adjusted to $35 \mathrm{mmHg}$ (STAT profile 3 analyzer; Nova Biomedical, Waltham, Mass., U.S.A.). Blood pressure was measured with a fluidfilled transducer coupled to the femoral artery catheter. A mid-arterial phase anteroposterior angiogram of the basilar artery was obtained by manual injection of $6 \mathrm{ml}$ iothalamate meglumine. Magnification and exposure factors were constant throughout the experiment and a magnification standard was included in each radiograph. The animal was placed in the prone position and tilted $30^{\circ}$ headdown. The cisterna magna was punctured under fluoroscopic control using sterile technique and a 22 gauge needle. Six to $8 \mathrm{ml} \mathrm{CSF}$ was withdrawn. Arterial blood, $0.5 \mathrm{ml} / \mathrm{kg}$, was withdrawn from the femoral artery catheter and injected into the cisterna magna over 15 minutes. After being positioned head down for a further 15 minutes, the animals were positioned in the right lateral decubitous position and the femoral artery catheter removed and the femoral artery ligated. This incision was closed and a Permacath dual lumen catheter (Quinton Instrument Co., Seattle, Wash., U.S.A.) was inserted into the left external jugular vein and advanced under fluoroscopy to the level of the right atrium. It was tunnelled to an exit site over the dorsal spine and connected to a CADD infusion pump (Pharmacia Deltec, St. Paul, Minn., U.S.A.) for continuous intravenous infusion. The pump was placed in a vest worn by the dog (Alice King Chatham Medical Arts, Los Angeles, Calif., U.S.A.). Animals were then awakened from anesthesia.

\section{Drug administration, day 7 angiography, eu- thanasia}

Starting on day 0 at the time of initial $\mathrm{SAH}$, drug vehicle or PD156707 were administered continuously through the central venous catheter as $0.3 \mathrm{mg} / \mathrm{kg} /$ day or an equivalent volume of drug vehicle. PD156707 was obtained from Parke-Davis (Ann Arbor, Mich., U.S.A.). Drug vehicle was L-lysine (Sigma Chemical Co., St. Louis, Mich., U.S.A.) in a concentration equal to that in the drug (approximately $35 \%$ ).

On day 2, dogs were anesthetized, positioned prone with the head $30^{\circ}$ down, and $0.5 \mathrm{ml} / \mathrm{kg}$ arterial blood was injected into the cisterna magna as described above. Drug administration continued until day 7 when the animals were reanesthetized and a femoral artery was exposed and catheterized. Angiography was repeated with the same magnification and exposure factors and with monitoring of and maintenance of vital signs and temperature in the physiological range as described above. After the day 7 angiogram, a Tracker-18 catheter (Target Therapeutics, San Jose, Calif., U.S.A.) was advanced into the anterior spinal artery which is the major contribution to the basilar artery in the dog. PD156707, $100 \mathrm{mg}$, or an equivalent volume of drug vehicle were infused into the basilar artery and angiography was repeated. CSF was aspirated from the cisterna magna for drug and ET levels. The animals were euthanized by intravenous administration of sodium pentobarbital. The basilar artery was removed and stored in liquid $\mathrm{N}_{2}$ along with all CSF and plasma samples for measurement of ET and drug levels. 


\section{Measurement of drug and ET levels}

PD156707 was measured by high pressure liquid chromatography (HPLC). ${ }^{25)}$ Briefly, plasma samples were subjected to solid-phase extraction using a phenyl bonded phase (1 mg/100 mg) (Bond Elut; Varian, Harbor City, Calif., U.S.A.) and a vacuum manifold. The PD156707 was detected in extracts by reverse phase HPLC using a C18 column $(5 \mu \mathrm{m}, 3.2$ $\times 150 \mathrm{~mm}$ ) with a mobile phase of acetonitrile-ammonium phosphate $(50 \mathrm{mM}, \mathrm{pH} 3.5)(44: 56, \mathrm{v} / \mathrm{v})$ run isocratically and detection fluorometrically.

ET levels were measured by enzyme immunoassay (Peninsula Laboratories, Inc., Belmont, Calif., U.S.A.). In this assay, there is reactivity with dog ET1 and ET-2 but not big ET-1, ET-3, or other small peptides such as atrial natriuretic peptide. Arteries were homogenized in $1 \mathrm{~mol} / \mathrm{l}$ acetic acid. Arteries and CSF samples were boiled for 10 minutes, centrifuged at $12,000 \mathrm{~g}$ for 20 minutes, dried under vacu$\mathrm{um}$, and resuspended in $0.2 \mathrm{ml}$ of assay buffer. Assays were then conducted according to methods provided by the kit manufacturer. Standards were prepared using known amounts of ET-1 and levels of ET-1 were also measured in four normal dog basilar arteries. All chemicals were reagent grade or better. ET recovery in the sample preparation procedure was $91 \%$. All measurements were made in triplicate.

\section{Statistical analysis}

The basilar artery diameter was measured on each angiogram using an optical micrometer at 4 points $1 \mathrm{~cm}$ apart starting proximal to the bifurcation. The mean was calculated, corrected for variation in magnification, and entered into a computer along with physiological variables, drug levels, and ET levels. Angiogram interpretation and data analysis were blinded. Comparisons were made within groups over time using paired t-tests. Comparisons between groups were made by unpaired t-tests and between multiple measurements by one-way analysis of variance followed by Tukey's multiple comparison procedure if significant variance was found. Vasospasm was also graded as none $(<10 \%$ reduction in diameter between day 0 and day 7), mild (10$<25 \%$ decrease), moderate ( $25-50 \%$ decrease), or severe ( $>50 \%$ decrease). Significance was taken at $p$ $<0.05$. All values are means $\pm \mathrm{SE}$.

\section{Results}

\section{Physiological variables}

The only significant difference in physiological variables between groups at each time or within groups over time was an increase in heart rate in the PD156707 group at day 7 compared to day 0 (Table 1). Infusion of PD156707 and drug vehicle into dogs in the vehicle group on day 7 was associated with a significant decrease in heart rate (Table 2). These

Table 1 Physiological variables on day 0 and day 7 , by group

\begin{tabular}{llrr}
\hline Day & \multicolumn{1}{c}{ Variable } & $\begin{array}{c}\text { Vehicle } \\
\text { group } \\
(\mathrm{n}=10)\end{array}$ & $\begin{array}{c}\text { PD156707 } \\
\text { group } \\
(\mathrm{n}=12)\end{array}$ \\
\hline $0 \quad$ weight $(\mathrm{kg})$ & $17 \pm 1$ & $15 \pm 1$ \\
& heart rate (bpm) & $134 \pm 7$ & $125 \pm 5$ \\
& blood pressure (mmHg) & $77 \pm 8$ & $61 \pm 4$ \\
& temperature ( $\mathrm{C})$ & $37 \pm 1$ & $37 \pm 1$ \\
& PaCO $_{2}(\mathrm{mmHg})$ & $48 \pm 5$ & $36 \pm 3$ \\
7 & weight $(\mathrm{kg})$ & $16 \pm 1$ & $15 \pm 1$ \\
& heart rate $(\mathrm{bpm})$ & $135 \pm 9$ & $145 \pm 5^{*}$ \\
& blood pressure $(\mathrm{mmHg})$ & $77 \pm 5$ & $72 \pm 6$ \\
& temperature ( $\left.{ }^{\circ} \mathrm{C}\right)$ & $37 \pm 1$ & $38 \pm 1$ \\
& PaCO $_{2}(\mathrm{mmHg})$ & $34 \pm 2$ & $39 \pm 3$ \\
\hline
\end{tabular}

Values are means $\pm \mathrm{SE} .{ }^{*} \mathrm{p}<0.005$ comparing within groups between day 0 and day 7 .

Table 2 Physiological variables on day 7 after infusion of PD156707 or vehicle, by group

\begin{tabular}{|c|c|c|c|c|c|}
\hline \multirow{2}{*}{ Group } & \multirow{2}{*}{ Variable } & \multicolumn{2}{|c|}{ Vehicle infusion } & \multicolumn{2}{|c|}{ PD156707 infusion } \\
\hline & & Before & After & Before & After \\
\hline \multirow{4}{*}{ Drug } & heart rate (bpm) & $147 \pm 9(5)$ & $121 \pm 4(5)^{*}$ & $151 \pm 8(4)$ & $136 \pm 5(4)$ \\
\hline & blood pressure (mmHg) & $77 \pm 10(5)$ & $56 \pm 13(5)$ & $53 \pm 3(4)$ & $95 \pm 15[4]$ \\
\hline & temperature $\left({ }^{\circ} \mathrm{C}\right)$ & $38 \pm 1(5)$ & $38 \pm 1(2)$ & $37 \pm 1(4)$ & $37 \pm 0(2)$ \\
\hline & $\mathrm{PaCO}_{2}(\mathrm{mmHg})$ & $42 \pm 2(4)$ & $28(1)$ & $36 \pm 5(4)$ & $36 \pm 2(2)$ \\
\hline \multirow[t]{4}{*}{ Vehicle } & heart rate $(\mathrm{bpm})$ & $151 \pm 8(4)$ & $123 \pm 5(4)^{*}$ & $129 \pm 13[4]$ & $136 \pm 5(4)$ \\
\hline & blood pressure $(\mathrm{mmHg})$ & $72 \pm 4(4)$ & $73 \pm 11(4)$ & $82 \pm 9(4)$ & $82 \pm 6(4)$ \\
\hline & temperature $\left({ }^{\circ} \mathrm{C}\right)$ & $38 \pm 1(3)$ & $38(1)$ & $37 \pm 1(4)$ & $36 \pm 1(4)$ \\
\hline & $\mathrm{PaCO}_{2}(\mathrm{mmHg})$ & $30 \pm 1(4)$ & $33 \pm 3(2)$ & $38 \pm 4(4)$ & $32 \pm 4(2)$ \\
\hline
\end{tabular}

Values are means $\pm \mathrm{SE} ; \mathrm{n}$ is in parentheses. ${ }^{*} \mathrm{p}<0.05$ comparing within groups between before and after infusion. 


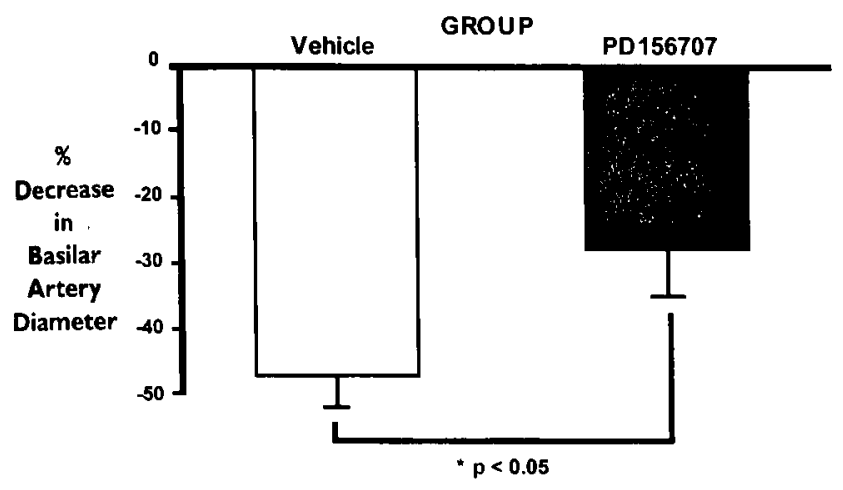

Fig. 1 Bar graph showing percent reduction in basilar arteries between day 0 and day 7 , for each group. Bars represent mean \pm SE. There were statistically-significant reductions in diameters in both the PD156707 and the vehicle groups (paired t-test, p $<0.05$ ) although at day 7 , there was significantly less vasospasm in the PD156707 group (unpaired t-test, $p<0.05$ ).

changes would not alter angiographic vessel diameters.

\section{Angiographic vasospasm}

Comparison of basilar artery diameters between day 0 and day 7 showed significant reductions in diameter in each group (vehicle: $-47 \pm 5 \%$, $p<$ 0.0001, PD156707: $-28 \pm 7 \%, p<0.005$, paired $t-$ tests) (Figs. 1 and 2). Comparisons of angiographic arterial diameters between groups at day 7 showed that the PD156707 had significantly less vasospasm than the vehicle group (unpaired t-test, $p<0.05$ ). There was also more likely to be no vasospasm in dogs receiving PD156707 compared to vehicle (Fig. 3). Infusion of PD156707 into the basilar artery on day 7 caused a small but significant $10 \pm 3 \%$ increase in diameter (paired t-test, $p<0.01$ ) compared to vehicle ( $3 \pm 3 \%$ increase, $p=0.32$ ). This effect was the same regardless of whether PD156707 was infused into animals in the PD156707 or vehicle groups (Fig. 4).

\section{Drug and ET levels}

Plasma drug levels were adequate to block responses of ET-1 on $\mathrm{ET}_{\mathrm{A}}$ receptors (Table 3). The drug crossed the blood brain barrier as shown by levels in CSF measured on day 2. Direct infusion of PD156707 into the basilar artery on day 7 also increased CSF levels approximately 500 times (from $37 \pm 23$ to $18,500 \pm 9500 \mathrm{ng} / \mathrm{ml}$ ).

The CSF ET-1 level was significantly greater than baseline by day 7 post-SAH in the PD156707 group.
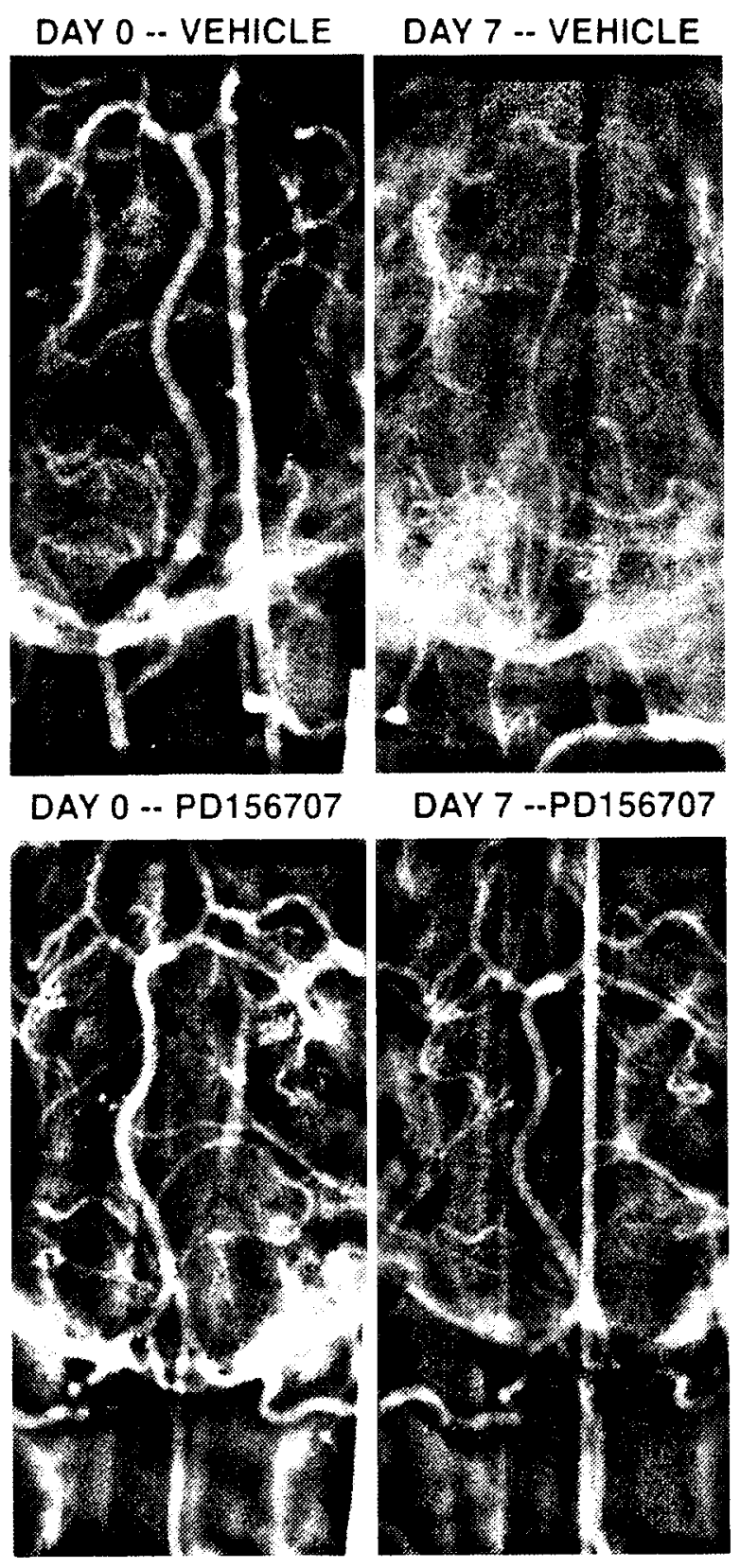

Fig. 2 Photographs of representative angiograms from dogs in each group, showing severe vasospasm in a dog in the drug vehicle group compared to no vasospasm in a dog in the PD156707 group.

A similar but slightly lower level was observed at day 7 in vehicle-treated animals. There were no differences in ET-1 levels in CSF between groups at any time (Fig. 5). In the basilar artery 7 days after SAH, ET-1 levels were higher in both PD156707- and vehicle-treated animals than in normal dog basilar artery although this was not statistically significant 


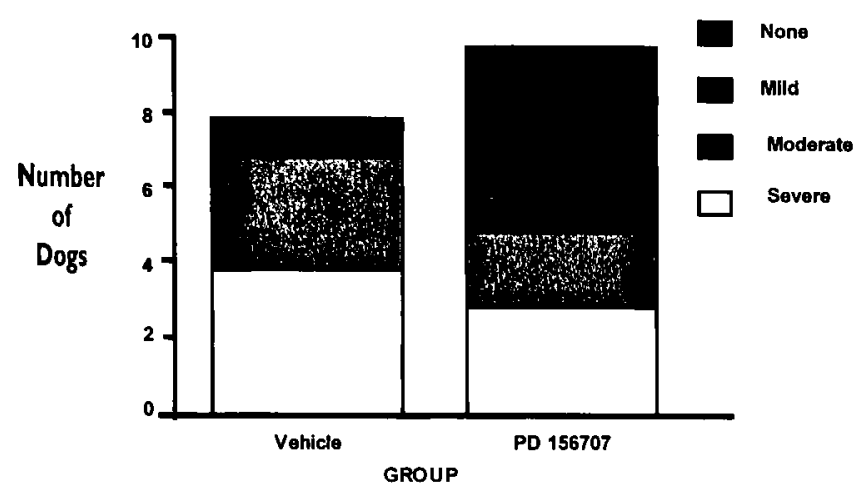

Fig. 3 Bar graph showing the number of dogs in each group with each grade of vasospasm of the basilar artery, with vasospasm graded as none $(<10 \%$ reduction in diameter), mild (10- $<25 \%$ reduction), moderate $(25-50 \%$ reduction), or severe ( $>50 \%$ reduction). More animals treated with PD156707 had no vasospasm.

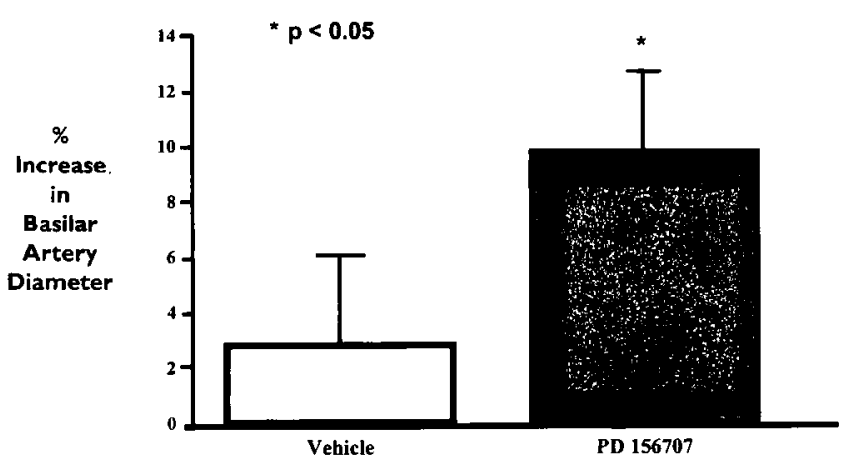

Fig. 4 Bar graph showing effect of superselective infusion of PD156707 or vehicle into the basilar artery on day 7 . Bars represent mean $\pm S E$. There were no differences in effect of PD156707 or vehicle infusion into dogs treated with PD156707 or vehicle so the groups were combined. There was a small but statistically significant increase in basilar artery diameter after infusion of PD156707 ( $<<0.05)$.

(Fig. 6).

\section{Discussion}

The nonpeptide competitive $\mathrm{ET}_{\mathrm{A}}$ receptor antagonist, PD156707, was shown to be a highly selective inhibitor of binding of ET-1 to the cloned human $\mathrm{ET}_{\mathrm{A}}$ receptor $\left(\mathrm{K}_{\mathrm{i}}=0.17 \mathrm{nmol} / \mathrm{l}\right)$ with less inhibition of binding to the $\mathrm{ET}_{\mathrm{B}}$ receptor $\left(\mathrm{K}_{\mathrm{i}}=\right.$ $134 \mathrm{nmol} / \mathrm{l}){ }^{24)}$ Activity against $\mathrm{ET}_{\mathrm{A}}$ receptor-mediat-
Table 3 Levels of PD156707 in plasma and cerebrospinal fluid

\begin{tabular}{llllcc}
\hline \multirow{2}{*}{ Day after SAH } & \multicolumn{2}{c}{ Plasma } & & \multicolumn{2}{c}{ Cerebrospinal fluid } \\
\cline { 2 - 3 } \cline { 5 - 6 } & $\mathrm{n}$ & Level $(\mathrm{ng} / \mathrm{ml})$ & & Level $(\mathrm{ng} / \mathrm{ml})$ \\
\hline 2 & 11 & $657 \pm 367$ & & 11 & $13 \pm 9$ \\
4 & 11 & $156 \pm 76$ & & \\
6 & 10 & $251 \pm 160$ & & \\
7 before super- \\
$\begin{array}{l}\text { selective infusion } \\
\text { after super- } \\
\text { selective infusion }\end{array}$ & $11243 \pm 178$ & & 5 & $37 \pm 23$ \\
\hline
\end{tabular}

Values are means \pm SE. SAH: subarachnoid hemorrhage.

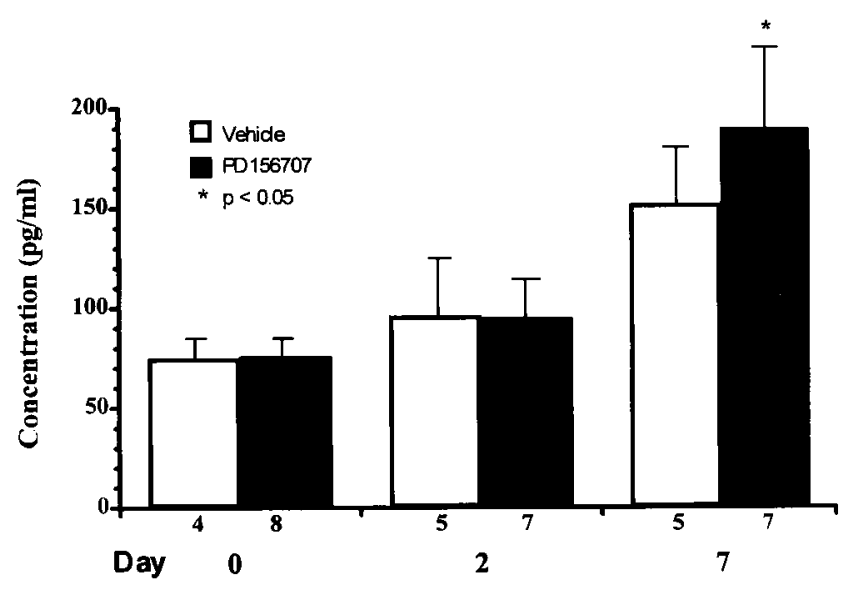

Fig. 5 Bar graph showing endothelin levels (pg/ml) in cerebrospinal fluid from each group. Bars represent mean $\pm S E$ and $n$ is shown below each bar. There is an increase with increased time after subarachnoid hemorrhage which is significant for animals treated with PD156707 (analysis of variance, $p$ $<$ 0.05).

ed effects have been demonstrated in vivo after oral administration of PD156707. This study shows that systemic administration of PD156707 decreases the severity of vasospasm after SAH in dogs. Vasospasm still occurred but was decreased to about $50 \%$ of control. This suggests that alterations in ET may be involved in the pathogenesis of vasospasm. In support of this, ET-1 levels were elevated in CSF 7 days after SAH. There was an increase in ET-1 in the basilar artery although this was not statistically significant due to the small number of samples examined. The only physiological change attributable to the drug was an increase in the heart rate of animals who received a week of intravenous PD156707. Hypoten- 


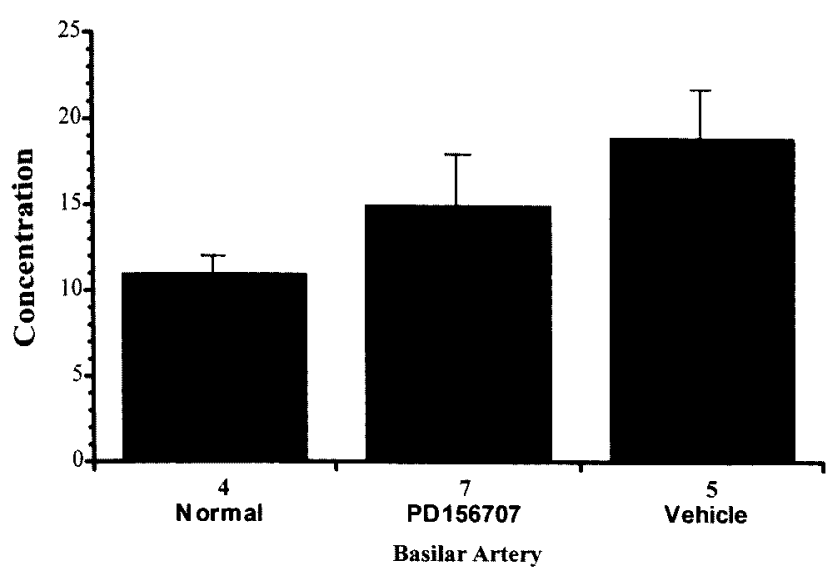

Fig. 6 Bar graph showing endothelin levels (pg/ml) in basilar arteries from each group. Bars represent mean $\pm \mathrm{SE}$ and $\mathrm{n}$ is shown below each bar. There are no differences between groups.

sion was not observed. Changes in heart rate were observed on day 7 in both groups after basilar artery infusions and are therefore probably not physiological effects of PD156707 but rather fluctuations that occur with the level of anesthesia.

The hypothesis that ET-1 causes vasospasm was based initially on measurements of ET levels after SAH. Five publications studied 92 patients and reported elevations of ET-1 in plasma and CSF of patients with SAH and that these increases were correlated with the time and severity of vasospasm. ${ }^{4,20,27,30,31)}$ Four reports were unable to demonstrate increases in ET-1 or that there was any correlation of CSF ET-1 levels or big ET-1 levels with SAH and vasospasm. ${ }^{6-8.17)}$ Some of the discrepancy may be secondary to the technical difficulties with accurately measuring ET levels. In addition, ET probably acts locally in an auto- or paracrine fashion so CSF or plasma levels may not accurately reflect processes occurring at the vasospastic arteries. In this experiment, ET-1 was increased in CSF but not significantly in the spastic basilar artery although the magnitude of increase in the basilar artery was of the same degree as was noted in other experiments in the double hemorrhage dog model. ${ }^{26)}$ Yamaura et al. found that ET-1, as measured by immunoassay, was increased at 2 but not 7 days after $\mathrm{SAH}$ in dogs whereas others noted increases in the basilar artery 7 days after SAH in dogs using immunohistochemical methods. ${ }^{11,33)}$ Hirose et al. ${ }^{11)}$ induced a larger-volume SAH than Yamaura et al., ${ }^{33)}$ suggesting that the time course and degree of elevation of ET-1 may be influenced by the type of SAH and possibly by other factors. Overall, the data sup- port an association between increased ET-1 levels and the post-SAH state. The association, however, does not prove that ET-1 causes vasospasm since ET-1 is elevated in other conditions that are not associated with vasospasm. ${ }^{9,171}$

Since ET-1 secretion is controlled mainly at the level of transcription, changes in ET-1 messenger ribonucleic acid (mRNA) might be expected to occur after SAH. Hino et al., ${ }^{9)}$ however, found no change in ET-1 mRNA 7 days after SAH in monkeys although there was an increase in $\mathrm{ET}_{B}$ receptor in vasospastic artery and in $\mathrm{ET}_{\mathrm{A}}$ and $\mathrm{ET}_{\mathrm{B}}$ receptors in the cerebral cortex. These changes were postulated to be compensatory changes to increase cerebral blood flow after SAH. They were similar to changes reported in ET receptor binding after SAH in dogs ${ }^{26)}$ The data suggest that alterations in ET and ET receptors occur after SAH but that they may be secondary to other pathophysiological processes involved in SAH.

That ET-1 causes vasospasm is also suggested by at least 19 studies of ET antagonists for prevention of vasospasm after experimental SAH. ${ }^{1-3.5,10-16,21,22,26,28,32,34-36)}$ The results have been variable and depend on a variety of factors such as the route and dose of drug adminstration, the model used, and the endpoints utilized. In summary, however, the majority of reports demonstrate that peptide antagonists such as BQ-123 have no or only a mild ${ }^{14)}$ effect on vasospasm when administered systemically but do if given intracisternally. The nonpeptide drug bosentan decreased vasospasm when administered systemically to rats, ${ }^{11}$ rabbits, ${ }^{26,36)}$ and $\operatorname{dogs}^{26,28,34)}$ but not when given intracisternally to monkeys. ${ }^{10)}$ These studies are limited by the lack of measurements of drug levels. Zuccarello et $\mathrm{al}^{36)}$ documented oral activity of PD1550808 and bosentan and showed that adequate drug levels were present in plasma to account for the effects.

How can the efficacy of ET antagonists and the evidence that ET-1 levels are increased after SAH be reconciled with data showing no changes in ET-1 levels after SAH and that most studies of antagonist drugs show that vasospasm is decreased but not completely prevented by these drugs. In fact, in the present study, only about $10 \%$ of established vasospasm was acutely reversible with direct intraarterial infusion of PD156707 which is much less than can be reversed with other agents such as papaverine. ${ }^{19,26)}$ Normal cerebrovascular tone is a balance between vasoconstricting substances (prostanoids, ET) and vasodilating substances (nitric oxide or a related nitroso compound). Since SAH impairs nitric oxidemediated relaxation of cerebral arteries, the remaining influence is ET-induced vasoconstriction, the blockade of which would then decrease vasospasm. 
Furthermore, decreased nitric oxide production increases ET-1 production. ${ }^{18.231}$ In addition, any secondary increase in ET-1 that might occur because of brain ischemia or trauma, conditions that have been associated with increased ET-1, would aggravate the situation. ${ }^{26)}$ This would acount for the beneficial effect of ET antagonists in the absence of consistent biochemical or molecular evidence in support of changes in ET-1 and for the observation that these drugs decrease vasospasm by about $50 \%$ but do not generally completely prevent it or reverse it when administered as a single bolus treatment for vasospasm.

In conclusion, continuous intravenous infusion of PD156707, a nonpeptide competitive antagonist of $\mathrm{ET}_{\mathrm{A}}$ receptors, significantly decreased vasospasm after SAH in dogs. Superselective intraarterial infusion of PD156707 into the basilar artery during established vasospasm in dogs also caused a small but statistically significant increase in basilar artery diameter.

\section{Acknowledgments}

This work was supported by grants to Dr. Macdonald from the National Institutes of Health and from Parke Davis Pharmaceuticals and by an American Association of Neurological Surgeons Young Clinician Investigator Award and American College of Surgeons Faculty Fellowship.

We thank Mr. David Blaber and Bard Access Systems (River Forest, Ill., U.S.A.) for supplying intravenous catheters.

\section{References}

1) Clozel M, Breu V, Burri K, Cassal JM, Fischli W, Gray GA, Hirth G, Löffler BM, Müller M, Neidhart W, Ramuz H: Pathophysiological role of endothelin revealed by the first orally active endothelin receptor antagonist. Nature 365: 759-761, 1993

2) Clozel M, Watanabe H: BQ-123, a peptidic endothelin $E T_{A}$ receptor antagonist, prevents the early cerebral vasospasm following subarachnoid hemorrhage after intracisternal but not intravenous injection. Life Sci 52: 825-834, 1993

3) Cosentino F, McMahon EG, Carter JS, Katušić ZS: Effect of endothelin ${ }_{\mathrm{A}}$-receptor antagonist BQ-123 and phosphoramidon on cerebral vasospasm. J Cardiovasc Pharmacol 22 (Suppl 8): S332-S335, 1993

4) Ehrenreich $H$, Lange $M$, Near KA, Anneser $F$, Schoeller LA, Schmid R, Winkler PA, Kehrl JH, Schmiedek P, Goebel FD: Long term monitoring of immunoreactive endothelin-1 and endothelin-3 in ventricular cerebrospinal fluid, plasma, and 24-h urine of patients with subarachnoid hemorrhage. Res Exp Med (Berl) 192: 257-268, 1992
5) Foley PL, Caner HH, Kassell NF, Lee KS: Reversal of subarachnoid hemorrhage-induced vasoconstriction with an endothelin receptor antagonist. Neurosurgery 34: 108-113, 1994

6) Fujimori A, Yanagisawa M, Saito A, Goto K, Masaki T, Mima T, Takakura K, Shigeno T: Endothelin in plasma and cerebrospinal fluid of patients with subarachnoid hemorrhage. Lancet 336: 633, 1991

7) Gaetani P, Rodriguez y Baena R, Grignani G, Spanu G, Pacchiarini L, Paoletti P: Endothelin and aneurysmal subarachnoid haemorrhage: a study of subarachnoid cisternal cerebrospinal fluid. J Neurol Neurosurg Psychiatry 57: 66-72, 1994

8) Hamann G, Isenberg E, Strittmatter M, Schimrigk K: Absence of elevation of big endothelin in subarachnoid hemorrhage. Stroke 24: 383-386, 1993

9) Hino A, Tokuyama Y, Kobayashi M, Yano M, Weir B, Takeda J, Bell GI, Macdonald RL: Increased expression of endothelin $B$ receptor mRNA following subarachnoid hemorrhage in monkeys. J Cereb Blood Flow Metab 16: 688-697, 1996

10) Hino A, Weir B, Macdonald RL, Thisted R, Kim CJ, Johns L: Prospective, randomized, double-blind trial of BQ-123 and bosentan for prevention of vasospasm following subarachnoid hemorrhage in monkeys. J Neurosurg 83: 503-509, 1995

11) Hirose $H$, Ide $K$, Sasaki T, Takahashi R, Kobayashi $M$, Ikemoto F, Yano M, Nishikibe M: The role of endothelin and nitric oxide in modulation of normal and spastic cerebral vascular tone in the dog. Eur J Pharmacol 227: 77-87, 1995

12) Ide $K$, Ito $S$, Sasaki $T$, Yano $M$, Kirino T: Effects of $\mathrm{ET}_{\mathrm{A}}$ receptor antagonist on normal and spastic canine basilar arteries, in Findlay JM (ed): Cerebral Vasospasm. Amsterdam, Elsevier, 1993, pp 213-216

13) Ikegawa R, Matsumura $Y$, Tsukahara $Y$, Takaoka $M$, Morimoto S: Phosphoramidon, a metalloproteinase inhibitor, suppresses the secretion of endothelin-1 from cultured endothelial cells by inhibiting big endothelin-1 converting enzyme. Biochem Biophys Res Commun 171: 669-675, 1990

14) Itoh S, Sasaki T, Asai A, Kuchino Y: Prevention of delayed vasospasm by an endothelin $\mathrm{ET}_{\mathrm{A}}$ receptor antagonist, BQ-123: change of $\mathrm{ET}_{\mathrm{A}}$ receptor mRNA expression in a canine subarachnoid hemorrhage model. J Neurosurg 81: 759-764, 1994

15) Itoh $S$, Sasaki T, Ide K, Ishikawa $K$, Nishikibe $M$, Yano $\mathrm{M}$ : A novel endothelin $\mathrm{ET}_{\mathrm{A}}$ receptor antagonist, BQ-485, and its preventive effect on experimental cerebral vasospasm in dogs. Biochem Biophys Res Commun 195: 969-975, 1993

16) Kim CJ, Bassiouny M, Macdonald RL, Weir B, Johns LM: Effect of BQ-123 and tissue plasminogen activator on vasospasm after subarachnoid hemorrhage in monkeys. Stroke 27: 1629-1633, 1996

17) Kraus GE, Bucholz RD, Yoon KW, Kneupfer MM, Smith KR Jr: Cerebrospinal fluid endothelin-1 and endothelin-3 levels in normal and neurosurgical patients: a clinical study and literature review. Surg Neurol 35: 20-29, 1991 
18) Lüscher TF, Boulanger CM, Dohi Y, Yang Z: Endothelium-derived contracting factors. Hypertension 19: $117-130,1992$

19) Macdonald RL, Zhang J, Sima B, Johns L: Papaver. ine-sensitive vasospasm and arterial contractility and compliance following subarachnoid hemorrhage in dogs. Neurosurgery 37: 962-968, 1995

20) Masaoka H, Suzuki R, Hirata $Y$, Emori T, Marumo F, Hirakawa K: Raised plasma endothelin in aneurysmal subarachnoid hemorrhage. Lancet 2: 1402-1403, 1989

21) Matsumura $Y$, Ikegawa $R$, Suzuki $Y$, Masanori $T$, Uchida T, Kido $H$, Shinyama $H$, Hayashi $K$, Watanabe M, Morimoto S: Phosphoramidon prevents cerebral vasospasm following subarachnoid hemorrhage in dogs: the relationship to endothelin-1 levels in the cerebrospinal fluid. Life Sci 49: 841-848, 1991

22) Nirei H, Hamada K, Shoubo M, Sogabe K, Notsu $Y$, Ono $\mathrm{T}$ : An endothelin $\mathrm{ET}_{\mathrm{A}}$ receptor antagonist, FR139317, ameliorates cerebral vasospasm in dogs. Life Sci 52: 1869-1874, 1993

23) Pluta RM, Boock RI, Afshar JK, Clouse K, Bacic M, Ehrenreich H, Oldfield EH: The source and cause of endothelin-1 release to cerebrospinal fluid after subarachnoid hemorrhage. J Neurosurg 87: 287-293, 1997

24) Reynolds EE, Keiser JA, Haleen SJ, Walker DM, Olszewski B, Schroeder RL, Taylor DG, Hwang O, Welch KM, Flynn MA, Thompson DM, Edmunds JJ, Berryman KA, Plummer $M$, Cheng XM, Patt WC, Doherty AM: Pharmacological characterization of PD156707, an orally active $\mathrm{ET}_{\mathrm{A}}$ receptor antagonist. J Pharmacol Exp Ther 273: 1410-1417, 1995

25) Rossi DT, Hallak H, Bradford L: Liquid chromatographic assay for a butenolide endothelin antagonist (PD 156707) in plasma. J Chromatogr B Biomed Appl 677: 299-304, 1996

26) Roux SP, Loffler BM, Gray GA, Sprecher U, Clozel M, Clozel JP: The role of endothelin in experimental cerebral vasospasm. Neurosurgery 37: 78-86, 1995

27) Seifert V, Loffler BM, Zimmermann M, Roux S, Stolke D: Endothelin concentrations in patients with aneurysmal subarachnoid hemorrhage. Correlation with cerebral vasospasm, delayed ischemic neurological deficits, and volume of hematoma. J Neurosurg 82: $55-62,1995$

28) Shigeno T, Clozel M, Sakai S, Saito A, Goto K: The ef- fect of bosentan, a new potent endothelin receptor antagonist, on the pathogenesis of cerebral vasospasm. Neurosurgery 37: 87-91, 1995

29) Shigeno $Y$, Mima $T$, Yanagisawa $M$, Saito $A$, Fujumori A, Shiba R, Goto K, Kimura S, Yamashita K, Yanasaki Y, Masaki T, Takakura K: Possible role of endothelin in the pathogenesis of cerebral vasospasm. J Cardiovasc Pharmacol 17 (Suppl 7): S480-S483, 1991

30) Suzuki H, Sato S, Suzuki Y, Takekoshi K, Ishihara N, Shimoda S: Increased endothelin concentration in CSF from patients with subarachnoid hemorrhage. Acta Neurol Scand 81: 553-554, 1990

31) Suzuki R, Masaoka H, Hirata Y, Marumo F, Isotani E, Hirakawa K: The role of endothelin-1 in the origin of cerebral vasospasm in patients with aneurysmal subarachnoid hemorrhage. J Neurosurg 77: 96-100, 1992

32) Willette RN, Zhang H, Mitchell MP, Sauermelch CF, Ohlstein EH, Sulpizio AC: Nonpeptide endothelin antagonist. Cerebrovascular characterization and effects on delayed cerebral vasospasm. Stroke 25: 2450-2456, 1994

33) Yamaura I, Tani E, Maeda $Y$, Minami N, Shindo $H$ : Endothelin-1 of canine basilar artery in vasospasm. $J$ Neurosurg 76: 99-105, 1992

34) Zimmerman $M$, Seifert V, Löffler BM, Stolke D, Stenzel W: Prevention of cerebral vasospasm after experimental subarachnoid hemorrhage by RO 47 0203, a newly developed orally active endothelin receptor antagonist. Neurosurgery 38: 115-120, 1996

35) Zuccarello M, Lewis AI, Rapoport RM: Endothelin $\mathrm{ET}_{\mathrm{A}}$ and $\mathrm{ET}_{\mathrm{B}}$ receptors in subarachnoid hemorrhageinduced cerebral vasospasm. Eur J Pharmacol 259: R1-R2, 1994

36) Zuccarello M, Soattin GB, Lewis AI, Breu V, Hallak H, Rapoport RM: Prevention of subarachnoid hemorrhage-induced cerebral vasospasm by oral administration of endothelin receptor antagonists. I Neurosurg 84: 503-507, 1996

Address reprint requests to: R. L. Macdonald, M.D., Section of Neurosurgery, MC3026, University of Chicago Medical Center, 5841 South Maryland Avenue, Chicago, IL 60637, U.S.A. 